\title{
Surfzone-beach-dune interactions
}

\author{
P.A. Hesp \\ Department of Geography and Anthropology, 227 Howe Russell Geosci. Bldg., Louisiana State University, Baton Rouge \\ Louisiana, USA 70803.pahesp@1su.edu
}

\begin{abstract}
This paper reviews the wave-beach-dune model of beach and dune interactions formulated by Hesp [1982] for micro-tidal beaches in eastern and southern Australia, and examines additions to, and more recent research principally on that model, but also briefly examines other models based on sediment supply variations. The model contends that dissipative beaches are characterized by high wave driven sediment supply, wide, low gradient beaches, maximum fetch, maximum aeolian sediment transport, largest foredunes and largest dunefields or dune systems, while reflective beaches are the opposite (minimal wave and wind driven sediment transport, narrow steep beaches, small foredunes and limited dunefield /dune system development. Intermediate beaches display a trend from high to low transport conditions, foredune size and dunefield development with a trend from dissipative to reflective. Future research ideas are also presented.
\end{abstract}

\section{INTRODUCTION}

The original generation of the wave-beach-dune model of beach and dune interactions was formulated by Hesp [1982] for microtidal beaches in eastern and southern Australia, although it might be argued that it would work in many cases for meso-tidal beaches ( $<\sim 4 \mathrm{~m}$ range). Most of these beaches were apparently not limited in sediment supply during the Holocene transgression and particularly in the last 7000 years. Sea level crossed the present around 6,500 to 7000 years ago, rose a little higher (perhaps $1 \mathrm{~m}$ in eastern Australia) and eventually fell to the present following a typical southern hemisphere pattern.

The model development followed the publication of a robust micro-tidal beach model with reasonably high predictability [Wright and Short, 1984]. The beach model enabled one to classify micro-tidal beaches into six states with characteristic morphologies, mobility, and modes of erosion and accretion. Subsequent research has extended the original model to meso- and macro-tidal beaches [e.g. Short and Masselink, 1993; Masselink and Turner, 1999]. An understanding of beach and backshore morphology for different surfzone-beach types allowed Hesp [1982] to develop actual and theoretical links between backshore morphology, potential aeolian transport, foredune state and morphology, and dunefield type and development [Short and Hesp, 1982].

\section{SURFZONE-BEACH STATE}

The micro-tidal beach models classified beaches into six states, with the dissipative state at the high wave energy $(>2.5 \mathrm{~m})$ extreme and reflective state at the low wave energy $(<1 \mathrm{~m})$ extreme. Four intermediate beach states occur between these states [Wright et al, 1979; Short and Wright, 1983; Wright and Short, 1984]. Dissipative beaches are characteristically high wave energy beaches and have the highest potential onshore sediment supply [Hesp, 1988]. Note however, that beaches may also be dissipative because of the presence of very fine sand (hence low gradient), or abundant sand, so some dissipative beaches may, in fact, be low wave energy beaches. They are typically wide, display flat to concave morphologies (no berms), low gradients and minimal backshore mobility. The latter refers to the coefficient of variation of mean shoreline position (see Short [1999], his table 7.1), and in reality refers to the amount of volumetric and profile change the beach and backshore experiences over time and through erosion to accretion phases. Reflective beaches are characteristically low wave energy beaches with low potential onshore wave driven sediment transport. Note that they may also be moderate to high wave energy where sediments are coarse sand to boulders. They are relatively steep, narrow, linear to terraced (i.e. display a berm form) morphologies, with low backshore mobility. Intermediate beaches range from wide, relatively flat beaches with low gradient berms and low mobility at the higher energy end of the spectrum, through moderate width with beaches with pronounced berms and high mobility to narrow beaches and moderate to low mobility berms at the reflective end of the range. Rips dominate surf zone processes in the intermediate range (Figure 1).

\section{SURFZONE TO BEACH SEDIMENT TRANSPORT}

Hesp [1982; 1999] and Short and Hesp [1982] argued that dissipative surfzones had the highest potential wave driven onshore transport while reflective beaches had the lowest, based on observations of Holocene sediment volumes contained in barrier systems developed landwards of those beaches. Some have argued that this premise (highest onshore transport on dissipative beaches, lowest on reflective) is fallacious, partly it seems because (i) there are minimal measurements of surfzone sediment transport, (ii) some of the measurements that exist tend to show that dissipative beaches are characterized by offshore transport (but not all - see e.g. Aagaard et al. [2004]; Miot da Silva [2011, in review]), (iii) models such as SBEACH and CROSMOR generally predict offshore transport [e.g. Larson and Kraus, 1989; van Rijn et al., 1999; Aagaard et al., 2002], and (iv) the observational time scales are substantially different (hours to days for surfzone observations versus 6-7000 years for Holocene barrier volumetric calculations). 

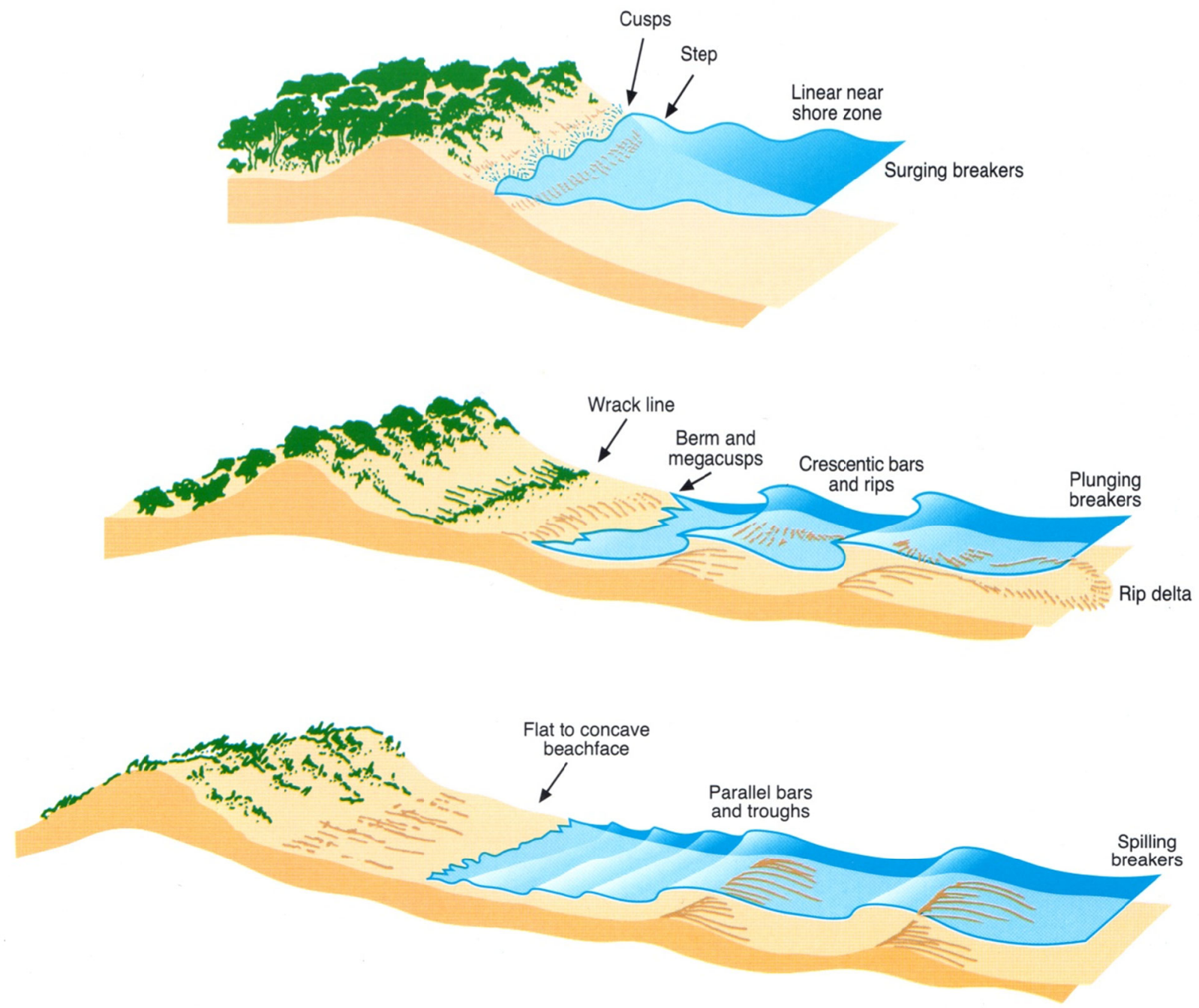

Figure 1. Schematic diagrams of the three micro-tidal surfzone-beach types, dissipative, intermediate and reflective. Also shown are the typical (for temperate environments) foredune stages and vegetation cover (modified from [Hesp, 2000]).

As Aagaard et al. [2004] note, "most field and laboratory observations suggest that the transport of sand and the movement of nearshore bars are directed offshore when the waves are breaking" (p. 206). Despite this, large-scale coastal evolution models predict onshore sediment transport and barrier formation during rising sea levels (given a suitable substrate gradient) [e.g. Roy et al., 1994; Cowell et al recent papers], and geological research of various barrier types indicates the same [e.g. Woodroffe, 2002; Davis and Fitzgerald, 2004; Dillenburg and Hesp, 2009]. It is also a fact that very many of the largest barrier and coastal dunefields in the world are found on high energy dissipative and high energy intermediate beaches (see Hesp [in press]).

Houser [2009] states that "existing beach-dune models do not consider how and when sediment gets transferred to the backshore..." (p. 742). The wave-beach-dune model does not examine nor predict the "how" of grain by grain transport, nor concern itself with bar migration and sediment delivery to the beach, but there are an increasing number of studies that have and do [e.g. Wijnberg and Kroon, 2002; Shand et al., 2003; Aagaard et al., 2004, 2011; Miot da Silva and Hesp, 2010; plus the Argus observation systems worldwide], and certainly more are required. However, for the scale of model building examined by Hesp [1982] and others [e.g. Psuty, 1988, 2004; Sherman and Bauer, 1993] this is unnecessary since, in fact, the wave-beach-dune model explicitly considers the net sediment delivery to the beach by providing long term data on beach-surfzone profiles and their dynamics (width, mobility, modal state, modes of erosion and accretion etc.; - see Figure 7.7 in Short [1999]; and profile measurements by e.g. Sonu [1973]; Holman and Bowen [1982]; Stive and deVriend [1995]; Stive et al. [1999] and many others ). These data have been, or can be utilized to examine "when" sediment is delivered to the beach by scrutinizing the profile data and associated wave energies for various beaches [e.g. Short, 1979], but again, this is unnecessary for model building at mesoand macro-scales. The beach profile data provide evidence of sediment delivery to, and from the beach, the "how" is therefore irrelevant to meso-scale model building, and defining modal surfzone-beach behavior is the only necessary criteria required for the next step linking the beach supply to the dunes. 


\section{BEACH-BACKSHORE WIDTH AND MORPHOLOGY, FETCH, AND POTENTIAL AEOLIAN TRANSPORT}

Beach width is important in determining fetch which is critical for determining the volume of sand delivered across the backshore and to dunes [Davidson-Arnott, 1988, 2010; Davidson-Arnott and Law, 1996; Bauer and Davidson-Arnott, 2002; Houser, 2009]. Dissipative beaches display the widest morphologies and hence have the highest potential fetches compared to reflective beaches with a gradient from wide to narrow through the intermediate range. There are constraints however, not noted in the original model, including (i) at low tide, dissipative beaches may have a considerable wet to moist zone due to groundwater drainage, and (ii) as one moves from the micro-tidal to meso- and macro-tidal ranges, groundwater drainage is significant and the width of the dry upper beach can be limited.

Beach morphology is important because the greater the morphological variability, the more likely that wind velocity decelerations and variations take place across the backshore. Hesp [1982; 1999] showed that the wind flow across a wide, low gradient but curvilinear, dissipative beach displayed minimal flow variation and gradually accelerated across the backshore, thus maximizing potential aeolian transport. The wind flow over the berm crest of an intermediate beach was accelerated but decelerated leeward of the berm crest. High narrow berms typical of some reflective beaches display significant flow disturbance and deceleration leeward of the berm crest [Short and Hesp, 1982] (see Figure 2).

Modeling by Sherman and Bauer [1993] indicates that the conceptual and empirical observations of Hesp [1982] and Short and Hesp [1982] are confirmed. Sherman and Lyons [1994] modeled wind flow and potential sediment transport across three beach morphologies: a flat beach, low berm and high berm profiles, and found that sand transport off the dissipative beach was $20 \%$ higher than off the reflective beach if just slope and grain size were taken into account. When moisture content was added, transport rates were nearly two orders of magnitude higher off the dissipative beach compared to the reflective beach. Note, however, that each beach had the same width (100m wide), whereas actual reflective beaches and many intermediate beaches are considerably narrower than dissipative beaches.

Beach mobility is important because the greater the beach mobility, the greater the morphological variability. The latter affects the fetch such that the beach width is at times quite narrow, at times quite wide, particularly for intermediate beaches. It is also important because alternating episodes of cut and fill result in varying beach morphologies which then affect airflow and sediment transport as indicated above.

Thus, the link between surfzone-beach state, aeolian sediment transport and landward dunes is that modal dissipative beaches have maximum potential aeolian sediment transport (low mobility, wide fetch, flat, low gradient morphology), reflective beaches have minimal potential aeolian sediment transport (low mobility, short fetch, steep, narrow beach and/or high narrow berms), and intermediate beaches range from relatively high potential at the dissipative end to low potential at the reflective end. Houser and Hamilton [2009] provide supporting evidence for these relationships in a study of surfzone-beach interactions in NW Florida.
Note that a minimal sediment supply ("minimal" is currently undetermined) is required.

\section{AEOLIAN SEDIMENT TRANSPORT AND FOREDUNE MORPHOLOGY}

An examination of foredune heights and volumes on dissipative to reflective beaches allows one to examine the validity of the links above. Since established foredunes occupy a foremost backshore position, they are a medium term indicator of beach and backshore processes. Hesp [1988] measured incipient and established foredune volumetric changes over several years at Myall Lakes National Park in NSW, Australia to find that a modal reflective beach with the same wind exposure as a modal dissipative beach received $60 \%$ less sand than the dissipative beach over the same survey period. Intermediate beach volumes ranged from relatively high to relatively low between the dissipative and reflective beaches.

Surveys of established foredunes, which have been present for potentially several hundred years, provide further evidence that there is a strong link between surfzone-beach type and foredune height and volume. Hesp [1982; 1988] demonstrated that in the Myall Lakes National Park in NSW, Australia, the smallest established foredunes, with lowest sediment volumes were found on reflective beaches, while the highest and largest foredunes occurred on dissipative beaches. Similar results are reported by Davidson-Arnott and Law [1990]. Intermediate beaches followed
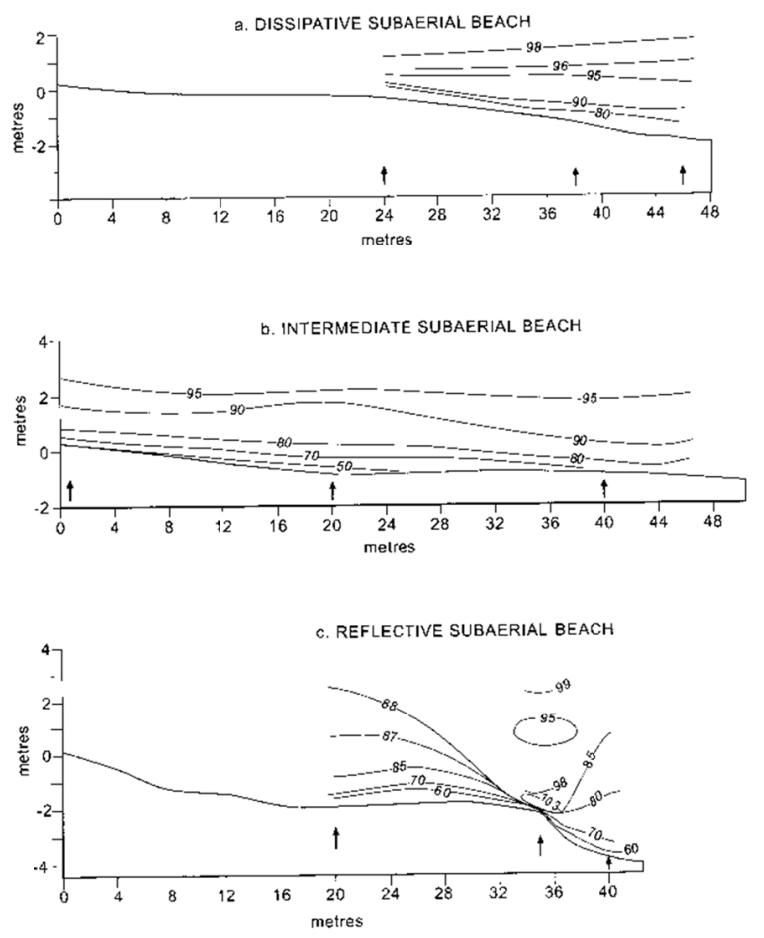

Figure 2. Mean wind speed iso-lines measured with cup anemometry over a dissipative, intermediate and reflective beach (modified from [Hesp, 1999]). An increase in topographic variability leads to an increase in wind field variability such that, on average, wind speeds are least disturbed, and show the greatest landward accelerations on dissipative beaches. 
a trend from low to high volumes on lowest to highest energy intermediate beaches respectively (see reviews in Sherman and Bauer [1993] - their Table 1, and Bauer and Sherman [1999]).

Miot da Silva and Hesp [2010] and Miot da Silva [2011; in review] examined wave driven sediment supply, winds, aeolian transport, foredune development and dunefield evolution for an embayment in southern Brazil and found that shoreline orientation to the predominant wind and wave regime was important in driving sediment delivery to foredunes, but also that the alongshore gradient in surfzone-beach type (low energy dissipative in the south, increasingly higher energy intermediate towards the north, moderate to high energy dissipative in the north) resulted in greater sediment supply towards the north and the largest foredunes occurred in the northern portion of the embayment.

Houser and Mathew [2011] found that an increase in available fetch was correlated with an increase in dune height. They further state however, that the washover channels occur on the widest and lowest gradient dissipative beaches, while the largest dunes on Padre Island are "fronted by a foreshore that is relatively steep and short" (p. 70). Note, however, their dissipative and intermediate beaches appear to be only slightly different in terms of gradient. They argue that the highest dunes occur where the backshore is higher and where there is more sediment available. They thus believe that sediment availability is more important there than transport potential. It is unlikely that 2 periods of Lidar observations as obtained by Houser and Mathew [2011] are sufficient to establish relationships about modal beach states. It is true that at times more intermediate beach-backshore profiles have higher berms and therefore less moist or wet surface areas than dissipative beaches, but the Short and Hesp [1982] model shows that it is the higher mobility of these beaches that reduces the long term sediment input to dunes, something that Houser and Mathew [2011] do not consider. In addition, dune height is a less useful parameter to use for estimating relationships between beach state, aeolian sediment delivery and dune development; estimates of dune volume provide a much more accurate means of determining such relationships.

\section{FOREDUNE ECOLOGY}

The vegetation cover, species richness and zonation of foredunes is determined by several factors, but sediment supply and sand deposition rate, and salt spray aerosol levels are two important factors [Hesp, 1991; Maun, 2009]. Simultaneous studies carried out on adjoining reflective, intermediate and dissipative beaches show that salt spray aerosol levels are related to surfzonebeach type. Dissipative beaches have the widest surfzones, the greatest number of breaking waves, and highest wave heights and the highest salt aerosol levels. Reflective beaches often have only one breaking wave, narrow to very narrow surfzones, and low wave heights and the lowest salt aerosol levels. All other factors being equal, foredune species richness and zonation tends to be greatest and narrowest respectively on reflective beaches (low sediment supply and salt aerosols), and lowest and widest on dissipative beaches (highest sediment supply, high salt aerosol levels [Hesp, 1988].

\section{FOREDUNE STABILITY AND TYPE, EROSION PROCESSES AND DUNEFIELD DEVELOPMENT}

Foredunes bear a morphological imprint dictated, in part, by modal surfzone-beach erosion and accretion modes, and the wind often accentuates this morphological imprint. Dissipative beaches are typically eroded by swash bores and undertow commonly associated with elevated water levels and storm surge. Beach erosion and dune scarping is laterally continuous alongshore, and at times catastrophic. Short and Hesp [1982] and Hesp [1988] theorized that such laterally continuous alongshore, large scale foredune scarping would on occasions lead to large scale foredune de-stabilization. Transgressive dunefields would most likely result from the breakdown of the large established foredune. In fact, whether foredunes exist or not, transgressive dunefields are most commonly found on high energy dissipative and high energy intermediate surfzone-beach systems (e.g. Australia, South Africa, Brazil coasts; west coast USA; east and west coast Mexico; NZ North Island west coast; Peru and Chile coasts; France, Spain and Portugal coasts). Recent research by Hesp et al. [2009], Martinho et al. [2009], Miot da Silva and Hesp [2010], and Miot da Silva [2011; in review] support this contention for southern Brazilian transgressive dunefield barrier systems.

Intermediate beaches are characterized by localized, arcuate rip embayment erosion during storms. Such arcuate erosion extends well into the foredune during extreme events resulting in large scale, but localized foredune scarping. Topographic funneling of the wind may result in the evolution of blowouts and eventually parabolic dunes at these locations. While Short and Hesp [1982] argued that higher energy intermediate beaches should be correlated with parabolic dune complexes, to date there has been little research conducted on this or evidence provided.

On SE Australian beach systems where overwash events are minor to absent, where sediment supply is generally not limited, and where an aggressive pioneer grass (Spinifex sp.) exists, relict foredune plains are common, particularly on the moderate energy intermediate beaches. Here established foredune stability is maintained to various degrees, and progradation over the last 6 7000 years has led to the development of foredune plains.

Reflective beaches are characterized by accentuated swash during storms and laterally continuous alongshore beach erosion. Recovery is fairly rapid. Foredunes remain relatively stable over time, and because they are typically small, with limited sediment supply, little dune transgression results. Thus reflective beaches are characterized by a single foredune, or a few relict foredunes.

\section{THE ROLE OF SEDIMENT SUPPLY}

Sediment supply is clearly a critical factor in all this. If there is no sediment supply, or very little, a dissipative surfzone-beach system will operate to use all the sediment available to build the surfzone and beach and there may be no dune at all. At the other extreme, a high to very high sediment supply on a low energy reflective beach will result in the development of a wide foredune plain. Several examples may be found on the Western Australian coast, for instance.

Psuty [1988, 2004] has produced several versions of a beachdune model which uses sediment supply alone as the single factor driving changes or spatio-temporal evolutionary sequences to 
foredunes (and sometimes other dune types). In these models high sediment supply from the beach and a negative dune budget results in the development of low foredunes or "beach ridges" (as indicated by Psuty [1988]), but this only applies strictly to foredunes, not any other dune types or systems. In addition, as Davidson-Arnott [2010] notes "in nature it is difficult to conceive of a situation with a large positive littoral sediment budget and negative dune budget so the curve on the right side of the diagram should more realistically flatten off around the neutral line" (p.263). Additionally, the creation of the curve is these models is unexplained, blowouts and parabolic dunes are only formed in negative beach budget situations (not true for many parabolic dune and transgressive dunefield systems), and the lower range of "present day dune development" compared to the "maximum"(?) development scenario (see Psuty [1988], figure 3) remains unexplained.

\section{OTHER FACTORS}

There is no doubt that sediment supply, wind energy, sea level state (transgressive, stable, regressive), return interval and magnitude of extreme storm events, and Pleistocene inheritance factors will all, at times, and in some places, be a controlling variable in beach-dune interactions. If sediment supply is limited, sea level is rising, and coastal erosion is the general rule, the models reviewed above may not work in part or perhaps at all.

\section{FUTURE STUDIES}

In order to move forward with the development of a more robust, higher predictability model (or models) we need to (at least):

(i) skill and field test present models and develop new models of surfzone and beach sediment transport;

(ii) conduct more combined wind flow and sand transport experiments across beaches of the modal types (dissipative through to reflective);

(iii) conduct computer model experiments of flow over different beach types;

(iv) obtain more data on surfzone-beach states, wave driven sediment transport over long time intervals for different surfzone-beach types, and compile data on their attendant dune systems in order to further test linkages between surfzone-beach and dune interactions;

(v) extend the models to meso-, macro-tidal and ultradissipative beach types;

(vi) develop a universal classification and definitions of low, medium and high sediment supply;

(vii) find coastal sites where it is possible to test (hopefully) one of the major factors driving coastal evolution at a time (e.g. marine and aeolian sediment supply, wave energy, wind energy, etc).

This list is not exhaustive.

\section{ACKNOWLEDGEMENT}

A special thanks to Douglas Sherman and Graziela Miot da Silva for their advice and assistance, Kathelijne Wijnberg for the invitation and support to attend the NCK-days 2012, and LSU and the NSF for grant and logistical support.

\section{REFERENCES}

Aagaard, T., Black, K.P. and Greenwood, B., 2002. Cross-shore suspended sediment transport in the surf zone: a field based parameterization. Marine Geology 185: 283-302.

Aagaard, T., Davidson-Arnott, R., Greenwood, B., and Nielsen, J., 2004. Sediment supply from shoreface to dunes: linking sediment transport measurements and long term morphological evolution. Geomorphology 60: 205-224.

Aagaard, T., Hughes, M.G. and Greenwood, B., 2011. Sediment transfer from bar to beach? Measurements using a pulsecoherent acoustic Doppler profiler. J. Coastal research SI 64: 2002-2006.

Bauer, B.O. and Davidson-Arnott, R.G.D., 2002. A general framework for modelling sediment supply to coastal dunes including wind angle, beach geometry, and fetch effects. Geomorphology 49: 89-108.

Bauer, B.O. and Sherman, D.J., 1999. Coastal Dune dynamics: Problems and prospects. In: A.S. Goudie, I. Livingstone and S. Stokes (eds), Aeolian Environments, Sediments and Landforms, 71-104. Chichester: J. Wiley and Sons

Davidson-Arnott, R.G.D., 1988. Temporal and spatial controls on beach/dune interaction, Long Point, Lake Erie; in: N.P. Psuty (ed), Dune/Beach Interaction. J. Coastal Research Special Issue No. 3: 131-136.

Davidson-Arnott, R.G.D., 2010. Introduction to Coastal Processes and Geomorphology. Cambridge Univ. Press, 442pp.

Davidson-Arnott, R.G.D. and Law, M.N., 1990. Seasonal patterns and controls on sediment supply to coastal foredunes, Long Point, Lake Erie; in: K.F. Nordstrom,

K.F. Psuty and R.W.G. Carter (Eds), Coastal Dunes: Form and Process, 177-200. Chchester: John Wiley and Sons.

Davidson-Arnott, R.G.D. and Law, M.N. 1996. Measurement and prediction of long-term sediment supply to coastal foredunes. J. Coastal Research 12 (3): 654-663.

Davis, R.A. Jr. and Fitzgerald, D.M., 2004. Beaches and Coasts. Blackwell Publishing, 419pp.

Dillenburg, S. and Hesp, P.A. (Editors), 2009. Geology and Geomorphology of Holocene Coastal Barriers of Brazil. Springer-Verlag Lecture Notes in Earth Sciences 107. Springer.

Dillenburg, S.R. and Hesp, P.A., 2009. Coastal Barriers - An Introduction. Chpt 1 in: S. R. Dillenburg and P. A. Hesp (Eds), Geology and Geomorphology of Holocene Coastal Barriers of Brazil. Lecture Notes in Earth Sciences, Vol 107: 1-15. Springer.

Hesp, P.A., 1982. Morphology and Dynamics of Foredunes in S.E. Australia. Unpubl. Ph.D Thesis, Dept. Geography, University of Sydney.

Hesp, P.A., 1988. Surfzone, beach and foredune interactions on the Australian south east coast. J. Coastal Research Spec. Issue 3: $15-25$.

Hesp, P.A., 1991. Ecological processes and plant adaptations on coastal dunes. J. Arid Environments 21: 165-191

Hesp, P.A., 1999. The Beach Backshore and Beyond. In: A.D. Short (Ed), Handbook of Beach and Shoreface Morphodynamics: 145-170. John Wiley and Sons, Chichester.

Hesp, P.A., 2000; Coastal Dunes. Forest Research (Rotorua) and NZ Coastal Dune Vegetation Network (CDVN): 28pp.

Hesp, P.A., P. C. F. Giannini, C. Thaís Martinho, G. Miot da Silva and N. E. Asp Neto, 2009. The Holocene Barrier Systems of the 
Santa Catarina Coast, Southern Brazil. Chapter 4 in: S. R. Dillenburg and P. A. Hesp (Eds), Geology and Geomorphology of Holocene Coastal Barriers of Brazil. Lecture Notes in Earth Sciences, Vol 107: 93-133. Springer.

Hesp, P.A., in press (due 2012). Dune coasts. In: Treatise on Estuarine and Coastal Science. Volume 3, Estuarine and Coastal Geology and Geomorphology. Elsevier. ISBN: 978-0-12374711-2.

Holman, R.A. and Bowen, A.J., 1982. Bars, bumps and holes: Models for the generation of complex beach topography. J. Geophysical research 87: 457-468.

Houser, C., 2009. Synchronization of transport and supply in beach-dune interaction. Progress in Physical Geography 33(6): 733-746.

Houser, C. and Hamilton, S., 2009. Sensitivity of post-hurricane beach and dune recovery to event frequency. Earth Surface Processes and Landforms 34: 613-628.

Houser, C. and Mathew, S., 2011. Alongshore variation in foredune height in response to transport potential and sediment supply: South Padre Island, Texas. Geomorphology 125: 62-72.

Larson, M., and Kraus, N.C., 1989. SBEACH: Numerical model for simulating storm-induced beach change. CERC TR 89-9, $256 \mathrm{pp}$.

Martinho, C.T., Dillenburg, S. R., Hesp, P.A., 2009. Wave energy and longshore transport gradients controlling barrier evolution in Rio Grande do Sul, Brazil. J. Coastal Research 25 (2): 285293.

Masselink, G. And Short, A.D., 1993. The effect of tide range on beach morphodynamics and morphology.: A conceptual beach model. J. Coastal Research 9: 785-800.

Masselink, G. and Turner, I., 1993. The effect of tides on beach morphodynamics. In: A.D. Short (Ed.) Handbook of Beach and Shoreface Morphodynamics: 204-229. J. Wiley and Sons Ltd.

Maun, M.A., 2009. The Biology of Coastal Sand Dunes. Oxford Univ. Press, 265pp.

Miot da Silva, G., 2011. Wave dynamics and beach - dune interactions: Moçambique Beach, Santa Catarina Island, Brazil. In: Wang, P.; Rosati, J.D.; Roberts, T.M., (Eds.) 2011. Proceedings Coastal Sediments, Miami, Florida, 1: 725-738.

Miot da Silva, G. and Hesp, P.A., 2010. Coastline orientation, aeolian sediment transport and foredune and dunefield dynamics of Moçambique Beach, southern Brazil. Geomorphology 120: 258-278.

Miot da Silva, G., Siadatmousavi, S.M. and Jose, F. (in review). Wave-driven longshore sediment transport and beach-dune dynamics in a headland bay beach. Submitted to Marine Geology.

Nickling, W.G. and Davidson-Arnott, R.G.D. (1990) Aeolian sediment transport on beaches and coastal sand dunes. Proc. Canadian Symposium on Coastal Dunes: 1-35.

Psuty, N.P., 1988. Sediment budget and beach/dune interaction, in: N.P. Psuty (Ed), Dune/Beach Interaction. J. Coastal Research Special Issue No. 3: 1-4.

Psuty, N.P., 2004. The coastal foredune: A morphological basis for regional coastal dune development. In: M. Martinez and N. Psuty (editors), Coastal Dunes, Ecology and Conservation. Ecological Studies v. 171. Springer-Verlag, Berlin: 11-27.

Shand, R.D., Bailey, D.G., Hesp, P.A., and Shepherd, M.J., 2003. Conceptual beach-state model for the inner bar of a stormdominated micro/meso tidal range coast at Wanganui, New Zealand. Proc. Coastal Sediments '03, 5th Internat. Symp. on Coastal Engineering and Science of Coastal Sediment Processes, May 18-23, Clearwater Beach, Florida, USA. (CDRom).

Sherman, D.J. and Bauer, B.O. (1993) Dynamics of beach-dune interaction. Progress in Physical Geography 17: 413-447.

Sherman, D. J. and Lyons, W. (1994) Beach-state controls on aeolian sand delivery to coastal dunes. Physical Geography 15 : 381-395.

Short, A.D., 1979. Three-dimensional beach stage model. J. Geology 87: 553-571.

Short, A.D., 1999. Wave-dominated beaches. In: Short, A.D. (Ed.), Handbook of Beach and Shoreface Morphodynamics: 173-203. J. Wiley and Sons Ltd.

Short, A.D. and Hesp, P.A. (1982) Wave, Beach and Dune interactions in South Eastern Australia. Marine Geology 48: 259-284.

Short, A.D. and Wright, L.D., 1983. Physical variability of sandy beaches. In McLachlan, A. and Erasmus, T. (Eds.) Sandy Beaches as Ecosystems. Junk, The Hague: 133-144.

Sonu, C.J., 1973. Three dimensional beach changes. Journal of Geology 81: 42-64.

Stive, M.J.F., deVriend, H.J., 1995. Modelling shoreface profile evolution. Marine Geology 126, 235- 248.

Stive, M.J.F., Cloin, B., Jimenez, J., Bosboom, J., 1999. Longterm cross-shoreface sediment fluxes. Proceedings Coastal Sediments '99. ASCE, New York, pp. 505- 518.

Van Rijn, L.C., Ruessink, B.G., and Grasmeijer, B.T., 1999. Generation and migration of nearshore bars under non-to macrotidal conditions. Proc. Coastal Sediments '99, ASCE: 463-478.

Wijnberg, K.M. and Kroon, A., 2002. Barred beaches. Geomorphology 48: 103-120.

Woodroffe, C.D., 2002. Coasts. Form, process and Evolution. Cambridge Univ. Press, 623pp.

Wright, L.D., Chappell, J., Thom, B.G., Bradshaw, M.P., and Cowell, P.J., 1979. Morphodynamics of reflective and dissipative beach and inshore systems, southeastern Australia. Marine Geokogy 32: 105-140.

Wright, L.D. and Short, A.D. (1984) Morphodynamic variability of beaches and surfzones: A synthesis. Marine Geology 56: 92118. 